J. Dairy Sci. 99:9875-9884

http://dx.doi.org/10.3168/jds.2016-11537

(C) 2016, THE AUTHORS. Published by FASS and Elsevier Inc. on behalf

of the American Dairy Science Association ${ }^{\circledR}$. This is an open access article under

the CC BY-NC-ND license (http://creativecommons.org/licenses/by-nc-nd/3.0/).

\title{
Milk acidification to control the growth of Mycoplasma bovis and Salmonella Dublin in contaminated milk
}

\author{
A. M. Parker, ${ }^{* 1}$ J. K. House, ${ }^{*}$ M. S. Hazelton, ${ }^{*}$ K. L. Bosward, ${ }^{*}$ V. L. Mohler, ${ }^{*}$ F. P. Maunsell, $†$ and P. A. Sheehy \\ *The University of Sydney, Faculty of Veterinary Science, School of Life and Environmental Sciences, Camden, New South Wales 2570 , Australia \\ †Department of Large Animal Clinical Sciences, College of Veterinary Medicine, University of Florida, Gainesville 32611
}

\begin{abstract}
Bacterial contamination of milk fed to calves compromises calf health. Several bacterial pathogens that infect cows, including Mycoplasma bovis and Salmonella enterica ssp. enterica serovar Dublin, are shed in milk, providing a possible route of transmission to calves. Milk acidification lowers the milk $\mathrm{pH}$ so that it is unsuitable for bacterial growth and survival. The objectives of this study were to (1) determine the growth of M. bovis and Salmonella Dublin in milk, and (2) evaluate the efficacy of milk acidification using a commercially available acidification agent (Salstop, Impextraco, Heist-op-den-Berg, Belgium) to control $M$. bovis and Salmonella Dublin survival in milk. For the first objective, 3 treatments and a positive control were prepared in $10 \mathrm{~mL}$ of milk and broth, respectively, and inoculated with $M$. bovis or Salmonella Dublin to an approximate concentration of $10^{4} \mathrm{cfu} / \mathrm{mL}$. Each treatment was retained at 5,23 , or $37^{\circ} \mathrm{C}$ with the positive control at $37^{\circ} \mathrm{C}$. Aliquots were taken at 4, 8, 24, 28, 32, 48, 52, and $56 \mathrm{~h}$ after inoculation and transferred onto agar medium in triplicate following a 10-fold dilution series in sterile phosphate-buffered saline. All plates were incubated and colonies counted. For the second objective, 4 treatments and a positive control were prepared with $100 \mathrm{~mL}$ of milk and inoculated with $M$. bovis or Salmonella Dublin to an approximate concentration of $10^{6} \mathrm{cfu} / \mathrm{mL}$. With the use of Salstop, treatments were adjusted to an approximate $\mathrm{pH}$ of $6,5,4$, or 3.5 . The positive control was left untreated. At 1, 2, 4, 6, 8, and $24 \mathrm{~h}$ after treatment, triplicate aliquots were taken, the $\mathrm{pH}$ measured, and then the aliquots were transferred onto agar medium and into broth for enrichment. Following incubation, agar colonies were counted, while broths were plated and incubated prior to colonies being
\end{abstract}

Received May 30, 2016.

Accepted July 27, 2016.

${ }^{1}$ Corresponding author: alysia.parker@sydney.edu.au counted. All trials were repeated. Mycoplasma bovis did not grow in milk, but Salmonella Dublin proliferated. The $\mathrm{pH}$ of all acidification treatments remained stable for $24 \mathrm{~h}$. No viable $M$. bovis organisms were detected at $1 \mathrm{~h}$ of exposure to $\mathrm{pH} 3.5$ and 4 or at $8 \mathrm{~h}$ of exposure to $\mathrm{pH} 5$. Following $24 \mathrm{~h}$ of exposure to $\mathrm{pH} 6 \mathrm{M}$. bovis remained viable. No viable Salmonella Dublin organisms were detected at 2 and $6 \mathrm{~h}$ of exposure to $\mathrm{pH} 3.5$ and 4, respectively. Salmonella Dublin remained viable following $24 \mathrm{~h}$ of exposure to $\mathrm{pH} 5$ and 6 . These results demonstrate that milk acidification using Salstop is effective at eliminating viable $M$. bovis and Salmonella Dublin organisms in milk if the appropriate $\mathrm{pH}$ and exposure time are maintained.

Key words: milk acidification, calf, dairy, Salmonella, mycoplasma

\section{INTRODUCTION}

Mycoplasma bovis can cause severe disease in cattle of all ages, and it is most commonly associated with mastitis and arthritis in adults (Wilson et al., 2007) as well as pneumonia, arthritis, and otitis media in calves (Maunsell and Donovan, 2009). Animals affected with clinical and subclinical mycoplasma mastitis can shed the organism through their milk at concentrations $\geq 10^{8}$ and $\leq 10^{6} \mathrm{cfu} / \mathrm{mL}$, respectively (Byrne et al., 2005). Cow-to-calf transmission of $M$. bovis can occur through the ingestion of infected milk (Maunsell et al., 2012). Because of the organism's highly contagious nature, unresponsiveness to antimicrobial treatment, and the role of subclinical carrier animals, elimination is difficult, and therefore, the focus is on preventing pathogen transfer (Maunsell et al., 2011).

Salmonella enterica ssp. enterica serovar Dublin is one of the most common Salmonella serotypes isolated from cattle, causing acute and subclinical disease in calves aged 2 wk to 3 mo (Wray and Davies, 2000). Clinical symptoms in calves include fever, ill thrift, depression, pneumonia, diarrhea, septicemia, and 
death (Mohler et al., 2009). Salmonella Dublin is host adapted to cattle and has a propensity to cause chronic subclinical infections. Calves infected with Salmonella Dublin that fail to clear the infection can remain as carrier animals within the herd, shedding the organism in feces and milk (Smith et al., 1989; House et al., 1993). As a result, approximately $50 \%$ of dairy herds that experience a Salmonella Dublin outbreak become persistently infected (Veling, 2004). Oral ingestion is the most common route of infection with a dose of $10^{6}$ cfu or greater leading to clinical symptoms (Wray and Sojka, 1977).

Current options to minimize exposure of calves to bacterial pathogens in milk include feeding milk replacer to eliminate access to contaminated milk, milk acidification, and pasteurization. Pasteurization may be achieved via heat or UV irradiation. Heat pasteurization of waste milk improves weight gain and reduces morbidity and mortality compared with feeding unpasteurized waste milk (Jamaluddin et al., 1996). Heat pasteurization is also an effective method of eliminating $M$. bovis and Salmonella Dublin to enable effective utilization of contaminated milk (Butler et al., 2000; Stabel et al., 2004). Despite this, the cost of purchasing an effective pasteurization unit is significant, with an economic analysis proposing a break-even point of 315 calves on milk per day, which equates to a herd milking 1,260 cows year-round (Jamaluddin et al., 1996). Treatment of waste milk by UV irradiation is less effective at reducing bacterial counts compared with heat pasteurization (Teixeira et al., 2013).

Although feeding of milk replacer avoids an initial capital outlay, it can be costly over time, and past evaluations have suggested that routine feeding with it may result in a poorer nutrient intake compared with whole pasteurized milk (Godden et al., 2005). Although both options provide a liquid feed that is initially free from viable M. bovis and Salmonella Dublin, both have the potential to become contaminated if placed into contaminated storage or feeding equipment. An alternative treatment approach is milk acidification, which involves lowering the $\mathrm{pH}$ of milk to a level that is unsuitable for bacterial growth and survival but still of nutritional benefit to calves (Anderson, 2008). A continued preservative effect persists while the $\mathrm{pH}$ remains at the effective level, and milk acidification is an economical alternative for smaller producers. A pilot trial in 2005 indicated that the total bacterial count in raw bulk tank milk (BTM) is reduced when the $\mathrm{pH}$ is lowered to 4.1 with the addition of formic acid (Anderson, 2005b). However very little information is available on specific contact times required to inactivate particular bacterial species. Furthermore, formic acid has substantial work health and safety hazards associated with its use.
Recently in light of these work health and safety issues, powdered forms have been made commercially available utilizing a combination of acids, but these have yet to be evaluated thoroughly for their efficacy.

The first objective of this study was to determine the growth and survival of $M$. bovis and Salmonella Dublin in inoculated milk over the course of $56 \mathrm{~h}$ at various incubation temperatures. The second objective of this study was to evaluate the efficacy of milk acidification using a commercially available feed acidification agent (Salstop, Impextraco, Heist-op-den-Berg, Belgium) to inhibit the growth and survival of M. bovis and Salmonella Dublin in inoculated milk over a period of $24 \mathrm{~h}$. In addition, the $\mathrm{pH}$ stability of "hospital herd" waste milk with high levels of bacterial contamination was evaluated following acidification using Salstop.

\section{MATERIALS AND METHODS}

\section{Acidifying Agent}

The commercially available product Salstop SD (Impextraco) was used as the acidifying agent throughout the trial. Salstop SD was selected based on its availability, feed grade status, and work health and safety characteristics (powder vs. liquid). According to the product information insert provided by the manufacturer, Salstop SD is a dry white powder preservative used to control Salmonella species and other pathogenic bacteria in raw materials and finishing feeds, and it prevents the recontamination of these materials. It contains a mixture of propionic, acetic, formic, sorbic, and lactic acids on a silica carrier.

\section{Preparing Bacterial Cultures}

Mycoplasma bovis type strain (ATCC 25523) was inoculated onto Mycoplasma agar [Mycoplasma agar base (Oxoid CM0401; Oxoid Inc., Basingstoke, UK); distilled water; $0.2 \% \mathrm{wt} / \mathrm{vol}$ calf thymus DNA (Sigma D1501, Sigma-Aldrich, St. Louis, MO); Mycoplasma Selective Supplement G (Oxoid SR0059C); prepared by Elizabeth Macarthur Agricultural Institute (EMAI), NSW Department of Primary Industries, NSW, Australia] and incubated at $37^{\circ} \mathrm{C}$ in candle jars with elevated $\mathrm{CO}_{2}$ levels for 5 to $10 \mathrm{~d}$. Following positive growth, several colonies were selected and subcultured into $2 \mathrm{~mL}$ of Mycoplasma broth [Mycoplasma broth base (Oxoid CM0403); Milli-Q water; $0.2 \%$ wt/vol calf thymus DNA (Sigma D1501); Mycoplasma Selective Supplement Q (Oxoid SR0059C); 0.4\% phenol red (Sigma P-3532); prepared by EMAI] at $37^{\circ} \mathrm{C}$ for $48 \mathrm{~h}$. After $48 \mathrm{~h}$ of incubation, $M$. bovis growth reached a concentration of approximately $10^{9} \mathrm{cfu} / \mathrm{mL}$ (data not shown). 
Salmonella Dublin strain 380, a kanamycin-resistant field isolate collected from the feces of a calf with scours (Izzo et al., 2011), was chosen for use in this study. The isolate allowed for the addition of kanamycin to the agar medium to prevent the growth of unwanted organisms that may have made plate reading difficult. Salmonella Dublin was inoculated onto xylose lysine deoxycholate (XLD) agar with kanamycin $(50 \mu \mathrm{g} / \mathrm{mL}$; EMAI) and incubated at $37^{\circ} \mathrm{C}$ for 24 to $48 \mathrm{~h}$. Following positive growth, several colonies were selected and subcultured into $2 \mathrm{~mL}$ of Luria broth (BD 241420) and incubated at $37^{\circ} \mathrm{C}$ for $24 \mathrm{~h}$. After $24 \mathrm{~h}$ of incubation, Salmonella Dublin 380 growth reached a concentration of approximately $10^{9} \mathrm{cfu} / \mathrm{mL}$ (data not shown).

\section{Milk Collection and Heat Treatment}

The milk used for all trials was BTM collected from The University of Sydney dairy. The University of Sydney dairy had no known history of $M$. bovis infection, but it did have a history of Salmonella Dublin infection. To reduce any existing bacterial contamination, the collected BTM was heat treated to $63 \pm 2^{\circ} \mathrm{C}$ for 30 min. All BTM was cultured for Mycoplasma spp. and Salmonella spp. as described above, before and after heat treatment. For all trials, no Mycoplasma spp. or Salmonella spp. growth was observed before or after heat treatment. However, because of the known history of Salmonella Dublin infection in this herd, a negative control was included for the Salmonella Dublin milk acidification trials.

\section{Bacterial Proliferation in Inoculated Milk}

Trials were performed independently for each organism. For all experiments involving M. bovis, Mycoplasma agar and Mycoplasma broth were used as described above. For all experiments involving Salmonella Dublin, XLD + kanamycin agar and Luria broth were used as described above.

Three treatment groups and a positive control broth were prepared in sterile $15-\mathrm{mL}$ polypropylene tubes (Biologix, Jinan, China) with $10 \mathrm{~mL}$ of milk (heat treated to $63 \pm 2^{\circ} \mathrm{C}$ for $30 \mathrm{~min}$ ) and broth, respectively. Each treatment and the positive control were inoculated with a volume of prepared organism broth culture to achieve a starting concentration of approximately $10^{4} \mathrm{cfu} / \mathrm{mL}$. To estimate the starting concentration of each treatment and control, an aliquot from each was removed and a 10-fold serial dilution in sterile PBS was performed. Each dilution was plated out in triplicate $10-\mu \mathrm{L}$ volumes onto the appropriate agar and incubated as previously described, followed by colony counting. Each treatment group was maintained at their assigned temperature of $5^{\circ} \mathrm{C}$ (refrigerator), $23^{\circ} \mathrm{C}$ (bench top), or $37^{\circ} \mathrm{C}$ (incubator), with the positive control broth placed in the incubator at $37^{\circ} \mathrm{C}$. Following inoculation and treatment, sampling occurred at 4, 8, $24,28,32,48,52$, and $56 \mathrm{~h}$. At each sampling interval, each treatment and control was subjected to a sampling protocol that involved vortexing followed by removal of $200 \mu \mathrm{L}$, which was subjected to a 10-fold serial dilution in sterile PBS, with each dilution inoculated onto the appropriate agar in triplicate $10-\mu \mathrm{L}$ volumes. All plates were incubated under the appropriate conditions for that bacterial species followed by colony counting. Each trial was repeated, and the results are reported as the mean of the replicated trials.

\section{Milk Acidification to Reduce the Bacterial Load in Milk}

Trials were performed independently for each organism. For trials with inoculated M. bovis or Salmonella Dublin, heat-treated milk was used $\left(63 \pm 2^{\circ} \mathrm{C}\right.$ for 30 min). For trials involving $M$. bovis, Mycoplasma agar and Mycoplasma broth were used as previously described, with the broth incubated for $4 \mathrm{~d}$. For trials involving Salmonella Dublin, XLD + kanamycin agar was used as previously described, and mannitol selenite broth, which was incubated at $37^{\circ} \mathrm{C}$ for $24 \mathrm{~h}$. To ensure that Salmonella Dublin was not already present within the milk, a negative treatment control was included containing $100 \mathrm{~mL}$ of heat-treated milk $\left(63 \pm 2^{\circ} \mathrm{C}\right.$ for $30 \mathrm{~min}$ ), which was not inoculated with Salmonella Dublin or treated with Salstop.

Four treatment groups and a positive control were prepared in sterile glassware with $100 \mathrm{~mL}$ of heat-treated milk. For each treatment and control, the milk was inoculated with the prepared organism in broth culture to achieve a starting concentration of approximately $10^{6} \mathrm{cfu} / \mathrm{mL}$. To estimate the starting concentration in each treatment and control tube, an aliquot from each was removed and a 10-fold serial dilution in sterile PBS was performed. Each dilution was plated out in triplicate $10-\mu \mathrm{L}$ volumes onto the appropriate agar and incubated under the appropriate conditions for each bacterial species followed by colony counting. For each treatment and control tube, three 2 -mL aliquots were also removed to measure the starting $\mathrm{pH}$ with a benchtop pH meter (labCHEM-pH, TPS, Brendale, QLD, Australia). Small increments of Salstop were added to each of the 4 treatment tubes followed by gentle but thorough mixing to ensure the entire additive was dissolved. A 2-mL aliquot was removed and the $\mathrm{pH}$ measured. This process was repeated on each of the 4 treatment tubes until they reached their approximate desired starting $\mathrm{pH}$ of $6,5,4$, and 3.5. Once 
the desired $\mathrm{pH}$ was achieved, the $\mathrm{pH}$ was measured in triplicate $2-\mathrm{mL}$ aliquots. The control tube remained untreated. All treatments and the control were placed on a benchtop at ambient temperature after which they were sampled following $1,2,4,6,8$, and $24 \mathrm{~h}$ of $\mathrm{pH}$ treatment exposure. At each sampling interval, the air temperature was recorded, and the following procedures were performed for each treatment and control. Visual observations of each milk treatment and control were noted. Milk was thoroughly mixed by gentle swirling of the tube and three $2-\mathrm{mL}$ aliquots were removed. To evaluate growth and viability of the organism, $10 \mu \mathrm{L}$ of each aliquot was inoculated onto the appropriate agar. To confirm the organism's viability and ensure that the concentration was not below the limit of detection by agar alone, a broth enrichment step was also included. This step involved transferring $10 \mu \mathrm{L}$ of each aliquot into $4 \mathrm{~mL}$ of the appropriate broth and incubating the mixture under appropriate conditions for each bacterial species. The $\mathrm{pH}$ of each aliquot was measured. Following incubation, each broth was inoculated onto the appropriate agar in $10-\mu \mathrm{L}$ volumes and incubated. Following incubation, colony counting was performed on all plates where possible or otherwise determined as "too many to count." The trial was repeated and results reported as the combined replicate trials.

\section{Stability of pH in Acidified High-Bacteria-Count Milk}

For total plate count trials to assess the $\mathrm{pH}$ stability of milk with a high bacterial load of mixed organisms, the method described in the previous section was used with the following modifications. Bulk hospital herd waste milk collected from the University of Sydney dairy was used. This milk was inoculated onto sheep blood agar (SBA; MicroMedia MM1337, Moe, VIC, Australia), but a broth enrichment step was not performed. At $24 \mathrm{~h}$ all treatments and the control had an aliquot of milk removed, which underwent a 10-fold serial dilution in sterile PBS followed by inoculation onto SBA in triplicate $10-\mu \mathrm{L}$ volumes. All SBA plates were incubated at $37^{\circ} \mathrm{C}$ for $24 \mathrm{~h}$ before analysis.

\section{Statistical Analysis}

For statistical analysis of bacterial proliferation in inoculated milk, a REML (GenStat 16th edition, VSN International, Hemel Hempstead, UK) analysis was performed on bacterial growth $\left(\log _{\mathrm{e}}\right)$ with trial as a random effect. Statistical significance was declared at $P<0.05$.

For milk acidification trials, bacterial growth results were converted to binary data as either growth (1) or no growth (0). A generalized linear mixed model (Gen-
Stat) analysis was performed on bacterial growth for time and treatment separately with trial as a random effect. This analysis was completed on bacterial growth before the enrichment broth and after enrichment broth for M. bovis and Salmonella Dublin. For Salmonella Dublin, the negative control data were excluded from analysis because no growth occurred at any sample time point.

\section{RESULTS}

\section{Bacterial Proliferation in Inoculated Milk}

For the M. bovis type strain (ATCC 25523) trials, the mean temperatures $( \pm \mathrm{SE})$ were $36.91^{\circ} \mathrm{C}( \pm 0.07)$ for the control and incubated milk, $22.94^{\circ} \mathrm{C}( \pm 0.17)$ for milk held at ambient temperature, and $5.77^{\circ} \mathrm{C}( \pm 0.23)$ for the refrigerated milk. The mean starting concentration ( $\pm \mathrm{SE}$ ) of $M$. bovis for all treatment groups was $5.30 \times 10^{3} \mathrm{cfu} / \mathrm{mL}\left( \pm 4.56 \times 10^{3}\right)$. Results of M. bovis proliferation in milk and broth are shown in Figure 1. The medium (milk or broth), temperature treatment, and time had a significant effect on bacterial growth and survival $(P<0.001)$. Proliferation occurred in the control broth tube incubated at $37^{\circ} \mathrm{C}$, achieving a peak mean concentration $( \pm \mathrm{SE})$ of $4.19 \times 10^{9} \mathrm{cfu} /$ $\mathrm{mL}\left( \pm 4.43 \times 10^{8}\right)$ after $52 \mathrm{~h}$. Milk treatment tubes incubated at 37 or $23^{\circ} \mathrm{C}$ had no viable organisms after $24 \mathrm{~h}$. For the milk treatment tubes refrigerated at $5^{\circ} \mathrm{C}$, the concentration of viable $M$. bovis organisms declined gradually over time but remained detectable at $56 \mathrm{~h}$ at a mean concentration $( \pm \mathrm{SE})$ of $2.5 \times 10^{2} \mathrm{cfu} / \mathrm{mL}( \pm$ $\left.1.83 \times 10^{2}\right)$. This amount is a $1.18-\log _{10}$ reduction from the starting concentration.

For the Salmonella Dublin strain 380 trials, the mean temperatures $( \pm \mathrm{SE})$ were $37^{\circ} \mathrm{C}( \pm 0.11)$ for the control and incubated milk, $23.3^{\circ} \mathrm{C}( \pm 0.18)$ for milk held at ambient temperature, and $6.2^{\circ} \mathrm{C}( \pm 0.05)$ for the refrigerated milk. The mean starting concentration $( \pm$ SE) of Salmonella Dublin for all treatment groups was $5.90 \times 10^{3} \mathrm{cfu} / \mathrm{mL}\left( \pm 4.17 \times 10^{3}\right)$. Results of Salmonella Dublin proliferation in milk and broth are shown in Figure 2. The temperature treatment and time had a significant effect on bacterial growth $(P<0.001)$. Proliferation of Salmonella Dublin was substantial in the control broth tubes incubated at $37^{\circ} \mathrm{C}$, as well as milk treatments held at 37 and $23^{\circ} \mathrm{C}$. For the control broth tubes incubated at $37^{\circ} \mathrm{C}$, the mean peak concentration of Salmonella Dublin $( \pm \mathrm{SE})$ was reached at 24 $\mathrm{h}$ with a concentration of $9.14 \times 10^{8} \mathrm{cfu} / \mathrm{mL}( \pm 1.19 \times$ $\left.10^{8}\right)$. This concentration remained stable, with a final concentration of $8.02 \times 10^{8} \mathrm{cfu} / \mathrm{mL}\left( \pm 1.43 \times 10^{8}\right)$ at $56 \mathrm{~h}$. For the milk treatment tubes incubated at $37^{\circ} \mathrm{C}$ the mean peak concentration of Salmonella Dublin ( \pm 


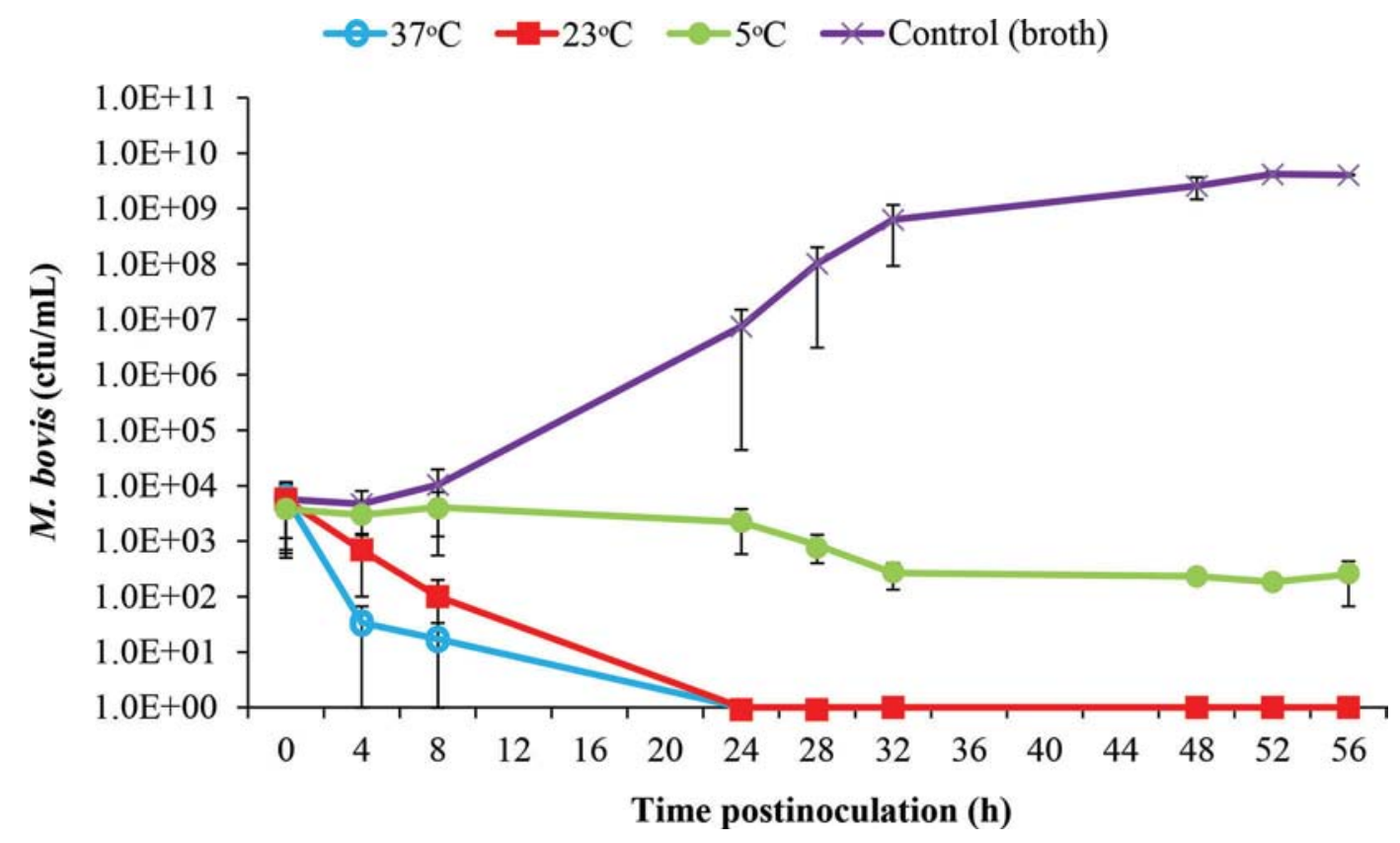

Figure 1. Mycoplasma bovis proliferation in milk at varying incubation temperatures over $56 \mathrm{~h}$. Results are expressed as the mean counts (cfu/mL; $\pm \mathrm{SE}$ ) of triplicates from 2 independent experiments.

$\mathrm{SE})$ of $2.03 \times 10^{9} \mathrm{cfu} / \mathrm{mL}\left( \pm 1.41 \times 10^{9}\right)$ was reached at $28 \mathrm{~h}$ with a decline in concentration to $3.25 \times 10^{6}$ $\mathrm{cfu} / \mathrm{mL}\left( \pm 2.29 \times 10^{6}\right)$ at $56 \mathrm{~h}$. For milk treatment tubes incubated at $23^{\circ} \mathrm{C}$, the mean peak concentration of Salmonella Dublin ( \pm SE) of $9.89 \times 10^{9} \mathrm{cfu} / \mathrm{mL}( \pm$
$6.04 \times 10^{9}$ ) was reached at $52 \mathrm{~h}$. For the milk treatment tubes refrigerated at $5^{\circ} \mathrm{C}$, the concentration of Salmonella Dublin remained stable throughout the 52-h treatment period, with a final mean concentration $( \pm$ $\mathrm{SE})$ of $5.30 \times 10^{3} \mathrm{cfu} / \mathrm{mL}\left( \pm 7.67 \times 10^{2}\right)$.

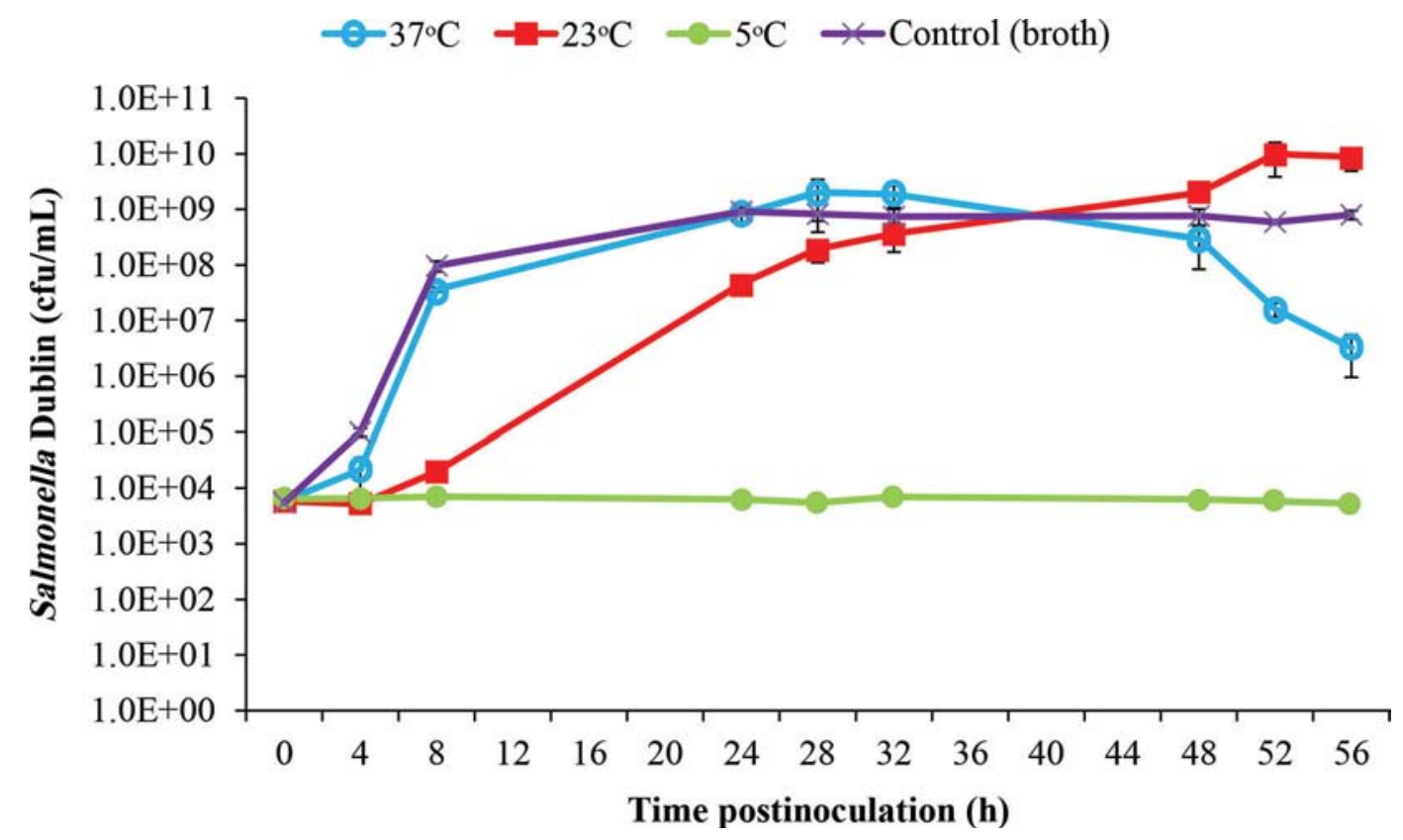

Figure 2. Salmonella Dublin proliferation in milk at varying incubation temperatures over $56 \mathrm{~h}$. Results are expressed as the mean counts (cfu/mL; $\pm \mathrm{SE}$ ) of triplicates from 2 independent experiments. 


\section{Milk Acidification to Reduce the Bacterial Load in Milk}

For the $M$. bovis type strain (ATCC 25523) trials, the mean ambient temperature $( \pm \mathrm{SE})$ for $24 \mathrm{~h}$ for the treatment tubes placed on the laboratory benchtop was $23.6^{\circ} \mathrm{C}( \pm 0.03)$. The $\mathrm{pH}$ of all treatment groups remained stable throughout $24 \mathrm{~h}$ to give a mean $\mathrm{pH}$ $( \pm \mathrm{SE})$ of $7.13( \pm 0.05)$ for the positive control tubes and $5.99( \pm 0.03), 5.18( \pm 0.11), 4.08( \pm 0.02)$, and $3.65( \pm 0.03)$ for the different treatment groups. The mean starting concentration $( \pm \mathrm{SE})$ of $M$. bovis for the control and all treatments was $1.36 \times 10^{6} \mathrm{cfu} / \mathrm{mL}( \pm$ $\left.2.8 \times 10^{4}\right)$. A significant difference existed in $M$. bovis survival between $\mathrm{pH}$ treatment groups before broth enrichment $(P<0.001)$ and following broth enrichment $(P<0.001)$. Results are shown in Table 1 and are reported as either growth or no growth. For milk treated to $\mathrm{pH} 4$ and $\mathrm{pH} 3.5$, no $M$. bovis growth was detected after $1 \mathrm{~h}$ of exposure time. For milk treated at $\mathrm{pH} 5$, no $M$. bovis growth was detected at $8 \mathrm{~h}$. Milk treated to $\mathrm{pH} 6 \mathrm{had}$ no $M$. bovis growth detected at $24 \mathrm{~h}$, but viable $M$. bovis organisms remained detectable at $24 \mathrm{~h}$ in nonacidified milk (positive control). Following enrichment in Mycoplasma broth, M. bovis viability was confirmed for all treatment tubes with the exception of $\mathrm{pH} 6$ (Table 1). Milk adjusted to $\mathrm{pH} 6$ showed no growth with direct inoculation onto Mycoplasma plates at $24 \mathrm{~h}$; however, following broth enrichment, viable $M$. bovis organisms were recovered.

For the Salmonella Dublin strain 380 trials, the mean ambient temperature $( \pm \mathrm{SE})$ for the treatment tubes placed on the laboratory benchtop for $24 \mathrm{~h}$ was $23.54^{\circ} \mathrm{C}$ $( \pm 0.01)$. The mean $\mathrm{pH}( \pm \mathrm{SE})$ over $24 \mathrm{~h}$ was 7.13 $( \pm 0.04)$ (negative control), $7.05( \pm 0.14)$ (positive control $), 6.19( \pm 0.03), 5.13( \pm 0.03), 4.05( \pm 0.03)$, and $3.67( \pm 0.03)$ for the treatment groups. The $\mathrm{pH}$ remained stable for $24 \mathrm{~h}$ for all treatment groups with the exception of the positive control, which experienced a slight decrease in $\mathrm{pH}$ at $24 \mathrm{~h}$ to 6.59 . The mean starting concentration $( \pm \mathrm{SE})$ of Salmonella Dublin for all inoculated treatment tubes was $6.83 \times 10^{5} \mathrm{cfu} / \mathrm{mL}( \pm$ $\left.6.33 \times 10^{3}\right)$. A significant difference existed in Salmonella Dublin survival between $\mathrm{pH}$ treatment groups before broth enrichment $(P<0.001)$ and following broth enrichment $(P<0.008)$. Results are shown in Table 2 and are reported as either growth or no growth. No Salmonella spp. were isolated from the negative control tubes. Milk adjusted to $\mathrm{pH} 3.5$ showed no Salmonella Dublin growth at $2 \mathrm{~h}$. Milk adjusted to $\mathrm{pH} 4$ showed no Salmonella Dublin growth at 6 h. Salmonella Dublin growth was still detected at $24 \mathrm{~h}$ in milk adjusted to $\mathrm{pH}$ 5 ; however, a reduction in the heaviness of growth was noted through visual observations. Milk adjusted to $\mathrm{pH}$ 6 and the positive control had Salmonella Dublin growth detected at all sampling time points. The positive control had visibly heavier growth at $8 \mathrm{~h}$ as compared with $0 \mathrm{~h}$. Following enrichment in mannitol selenite broth, Salmonella Dublin viability was confirmed for all $\mathrm{pH}$ treatments with the exception of $\mathrm{pH} 5$ at $24 \mathrm{~h}$, which showed no growth with direct inoculation onto XLD + kanamycin plates; however, viable Salmonella Dublin organisms were recovered following broth enrichment (Table 2). No growth of Salmonella spp. was observed in the negative control tubes at any sampling points.

\section{Stability of pH in Acidified High-Bacteria-Count Milk}

For the trials involving hospital herd waste milk to assess the $\mathrm{pH}$ stability of milk with a high initial

Table 1. Viability of Mycoplasma bovis in milk over $24 \mathrm{~h}$ following $\mathrm{pH}$ treatment with the commercially available milk acidifier Salstop (Impextraco, Heist-op-den-Berg, Belgium $)^{1}$

\begin{tabular}{|c|c|c|c|c|c|c|c|}
\hline Treatment & \multicolumn{7}{|c|}{ Duration of $\mathrm{pH}$ treatment $(\mathrm{h})$} \\
\hline \multicolumn{8}{|c|}{ Growth following acidification treatment $^{2}$} \\
\hline $\mathrm{pH} 6$ & G & G & G & G & G & $\mathrm{G}$ & NG \\
\hline $\mathrm{pH} 5$ & $\mathrm{G}$ & $\mathrm{G}$ & $\mathrm{G}$ & $\mathrm{G}^{3}$ & $\mathrm{G}^{3}$ & NG & NG \\
\hline $\mathrm{pH} 4$ & $\mathrm{G}$ & NG & NG & NG & NG & NG & NG \\
\hline Positive control & G & $\mathrm{G}$ & $\mathrm{G}$ & $\mathrm{G}$ & G & $\mathrm{G}$ & $\mathrm{G}$ \\
\hline pH 6 & $\mathrm{G}$ & $\mathrm{G}$ & $\mathrm{G}$ & $\mathrm{G}$ & $\mathrm{G}$ & $\mathrm{G}$ & $\mathrm{NG}^{3}$ \\
\hline $\mathrm{pH} 5$ & $\mathrm{G}$ & $\mathrm{G}$ & $\mathrm{G}$ & $\mathrm{G}^{3}$ & $\mathrm{G}^{3}$ & NG & NG \\
\hline $\mathrm{pH} 4$ & $\mathrm{G}$ & NG & NG & NG & NG & NG & NG \\
\hline $\mathrm{pH} 3.5$ & $\mathrm{G}$ & NG & NG & NG & NG & NG & NG \\
\hline
\end{tabular}

${ }^{1}$ Results are from triplicates of 2 independent trials and are represented by trial 1 .

${ }^{2}$ Colonies grown on Mycoplasma agar: $\mathrm{G}=$ growth; $\mathrm{NG}=$ no growth.

${ }^{3}$ Results that differed between trial 1 and 2 . 
Table 2. Viability of Salmonella Dublin in milk over $24 \mathrm{~h}$ following $\mathrm{pH}$ treatment with the commercially available milk acidifier Salstop (Impextraco, Heist-op-den-Berg, Belgium) ${ }^{1}$

\begin{tabular}{|c|c|c|c|c|c|c|c|}
\hline \multirow[b]{2}{*}{ Treatment } & \multicolumn{7}{|c|}{ Duration of $\mathrm{pH}$ treatment (h) } \\
\hline & 0 & 1 & 2 & 4 & 6 & 8 & 24 \\
\hline \multicolumn{8}{|c|}{ Growth following acidification treatment $^{2}$} \\
\hline Negative control & NG & NG & NG & NG & NG & NG & NG \\
\hline Positive control & $\mathrm{G}$ & $\mathrm{G}$ & $\mathrm{G}$ & $\mathrm{G}$ & $\mathrm{G}$ & $\mathrm{G}$ & $\mathrm{G}$ \\
\hline $\mathrm{pH} 6$ & $\mathrm{G}$ & $\mathrm{G}$ & $\mathrm{G}$ & G & $\mathrm{G}$ & $\mathrm{G}$ & $\mathrm{G}$ \\
\hline $\mathrm{pH} 5$ & $\mathrm{G}$ & $\mathrm{G}$ & $\mathrm{G}$ & $\mathrm{G}$ & $\mathrm{G}$ & $\mathrm{G}$ & $\mathrm{NG}^{3}$ \\
\hline $\mathrm{pH} 4$ & $\mathrm{G}$ & $\mathrm{G}$ & $\mathrm{G}$ & $\mathrm{G}^{3}$ & NG & NG & NG \\
\hline $\mathrm{pH} 3.5$ & G & $\mathrm{G}^{3}$ & NG & NG & NG & NG & NG \\
\hline \multicolumn{8}{|c|}{$\begin{array}{l}\text { Growth following acidification treatment and } \\
\text { broth enrichment }^{2}\end{array}$} \\
\hline Negative control & NG & NG & NG & NG & NG & NG & NG \\
\hline Positive control & G & G & G & G & G & G & G \\
\hline $\mathrm{pH} 6$ & $\mathrm{G}$ & $\mathrm{G}$ & $\mathrm{G}$ & $\mathrm{G}$ & $\mathrm{G}$ & $\mathrm{G}$ & $\mathrm{G}$ \\
\hline pH 5 & $\mathrm{G}$ & G & $\mathrm{G}$ & $\mathrm{G}$ & G & G & G \\
\hline $\mathrm{pH} 4$ & G & $\mathrm{G}$ & $\mathrm{G}$ & G & NG & NG & NG \\
\hline $\mathrm{pH} 3.5$ & $\mathrm{G}$ & $\mathrm{G}$ & NG & NG & NG & NG & NG \\
\hline
\end{tabular}

bacterial load of mixed organisms, the mean ambient temperature $( \pm \mathrm{SE})$ for the treatment tubes placed on the laboratory benchtop for $24 \mathrm{~h}$ remained stable at $23.18^{\circ} \mathrm{C}( \pm 0.12)$. The mean starting concentration $( \pm$ $\mathrm{SE}$ ) of total colony counts in the hospital herd milk was $8.53 \times 10^{5} \mathrm{cfu} / \mathrm{mL}\left( \pm 8.93 \times 10^{4}\right)$. For sampling time points of 1 through $8 \mathrm{~h}$, the total numbers of colonies grown were too many to count. At $24 \mathrm{~h}$, when the 10fold serial-dilution in PBS was performed, the mean concentration $( \pm \mathrm{SE})$ for the positive control was 1.82 $\times 10^{10} \mathrm{cfu} / \mathrm{mL}\left( \pm 1.40 \times 10^{10}\right)$, and for each treatment group was $1.35 \times 10^{10} \mathrm{cfu} / \mathrm{mL}\left( \pm 1.18 \times 10^{10}\right), 1.16 \times$ $10^{7} \mathrm{cfu} / \mathrm{mL}\left( \pm 3.92 \times 10^{5}\right), 3.48 \times 10^{5} \mathrm{cfu} / \mathrm{mL}( \pm 8.17$ $\left.\times 10^{4}\right)$, and $7.35 \times 10^{3} \mathrm{cfu} / \mathrm{mL}\left( \pm 4.35 \times 10^{3}\right)$ for $\mathrm{pH}$ $6, \mathrm{pH} 5, \mathrm{pH} 4$, and $\mathrm{pH} 3.5$, respectively. The mean $\mathrm{pH}$ ( $\pm \mathrm{SE}$ ) of milk over the course of $24 \mathrm{~h}$ following $\mathrm{pH}$ treatment using Salstop remained stable for $8 \mathrm{~h}$, with a mean $\mathrm{pH}( \pm \mathrm{SE})$ of $6.75( \pm 0.00)$ (positive control), $6.20( \pm 0.1), 5.09( \pm 0.07), 4.22( \pm 0.09)$, and $3.55( \pm$ 0.07 ). At $24 \mathrm{~h}, \mathrm{pH} 5,4$, and 3.5 remained stable; however, the $\mathrm{pH}$ of milk treated to an initial $\mathrm{pH}$ of 6 and the positive control decreased to a mean $\mathrm{pH}( \pm \mathrm{SE})$ of $4.58( \pm 0.10)$ and $4.36( \pm 0.10)$, respectively.

\section{Visual Observations of Milk Quality}

For all the milk acidification trials, treatments less than or equal to $\mathrm{pH} 5$ experienced milk separation with an obvious clear liquid top layer after $1 \mathrm{~h}$ of exposure. However, gentle swirling of the tube by hand returned the milk to a homogenous solution. Where the milk came into contact with the inside of the glassware dur- ing swirling, a thin film of fat adhered to the sides. Milk treated to $\mathrm{pH} 3.5$ was visibly thicker with a yogurt-like consistency, which was not evident in the other treatment groups.

\section{DISCUSSION}

Analysis of the growth of $M$. bovis type strain (ATCC $25523)$ in milk at 3 different temperatures $(5,23$, and $37^{\circ} \mathrm{C}$ ) demonstrated the organism's inability to proliferate in milk. When milk inoculated with $M$. bovis to a mean concentration $( \pm \mathrm{SE})$ of $3.79 \times 10^{3} \mathrm{cfu} / \mathrm{mL}( \pm$ $3.29 \times 10^{3}$ ) was refrigerated at $5^{\circ} \mathrm{C}$, a slight decline in viable organisms was observed; however, $M$. bovis could still be recovered from the milk at $56 \mathrm{~h}$. This latter finding is consistent with previous reports that demonstrated the ability of $M$. bovis to survive in milk refrigerated at $5^{\circ} \mathrm{C}$, with colony counts reduced by approximately $0.3 \log ^{10} \mathrm{cfu} / \mathrm{mL}$ in $5 \mathrm{~d}$ (Boonyayatra et al., 2010) and $0.46 \log ^{10} \mathrm{cfu} / \mathrm{mL}$ in 5 wk (Vyletelova, 2010). In contrast, in the present study, milk maintained at $23^{\circ} \mathrm{C}$ and incubated at $37^{\circ} \mathrm{C}$ saw a rapid decline in $M$. bovis growth with no viable organisms detectable at $24 \mathrm{~h}$. This trend was also observed in the M. bovis acidification trial with a higher starting concentration, whereby the concentration of viable $M$. bovis organisms decreased in the positive control over the course of $24 \mathrm{~h}$. This finding highlights the importance of appropriate storage and handling conditions for samples collected for diagnostic culture for $M$. bovis in the laboratory and supports the current recommendation that samples should be maintained at $4^{\circ} \mathrm{C}$ and transported to the 
laboratory as soon as possible if microbiological culture is to be performed (Maunsell et al., 2011). This observation also demonstrates that although milk is an adequate transport medium, it is not a sufficient nutrient source for $M$. bovis growth, a finding that is interesting in light of other studies that have suggested that Mycoplasma spp. could survive for up to $8 \mathrm{mo}$ in sand bedding, with the ideal temperature for survival being 15 to $20^{\circ} \mathrm{C}$ and the organism replicating at $4^{\circ} \mathrm{C}$ (Justice-Allen et al., 2010).

In contrast to $M$. bovis type strain (ATCC 25523), Salmonella Dublin strain 380 proliferated in milk at 23 and $37^{\circ} \mathrm{C}$, with maximum concentrations of $9.89 \times$ $10^{9} \mathrm{cfu} / \mathrm{mL}\left( \pm 6.04 \times 10^{9}\right)$ and $2.03 \times 10^{9} \mathrm{cfu} / \mathrm{mL}$ $\left( \pm 1.41 \times 10^{9}\right)$ reached, respectively, while survival remained stable at $5{ }^{\circ} \mathrm{C}$. Therefore, although storage of milk at $\geq 23^{\circ} \mathrm{C}$ may result in a decline in viable $M$. bovis organisms, the opposite effect was observed for Salmonella Dublin growth. Furthermore, although results suggest that $M$. bovis is unable to survive in milk for prolonged periods of time when left unrefrigerated, this study was conducted using milk that had been previously heat-treated to reduce the existing bacterial load before the inoculation of $M$. bovis, as well as using sterile glassware. Previous studies involving contaminated sand bedding have suggested the possibility of Mycoplasma spp. biofilm formation, with a positive association found between Mycoplasma spp. survival and the growth of gram-negative bacteria (Justice-Allen et al., 2010). Therefore, the use of heat-treated milk and sterile glassware may have affected the ability of $M$. bovis to survive in milk. As such, under normal farm conditions where it is likely that the milk being collected and fed to calves contains a mixed bacterial load and the containers used for storage and feeding of the milk may not be sterile (Stewart et al. 2005), the ability of $M$. bovis to survive in untreated milk may be altered. Although M. bovis was not shown to proliferate in milk, its ability to remain viable in milk for up to $8 \mathrm{~h}$ at ambient temperature explains how contaminated milk is able to infect calves because milk is often fed within a couple of hours of collection. This finding, in combination with the observed increase in Salmonella Dublin concentration over time at ambient temperature, means that seeking milk treatment options to reduce the bacterial load before feeding is warranted. Although treatment methods including heat pasteurization and UV treatment may reduce the total bacterial load of milk initially (Butler et al., 2000; Godden et al., 2006; Gelsinger et al., 2014; Pereira et al., 2014), the milk has the potential to become reinoculated once placed into nonsterile collection and feeding equipment (Stewart et al., 2005), allowing further proliferation of bacteria and as such limiting the health benefit of such treatments.
Therefore, acidification of the milk has benefits in providing a continued preservative effect when combating the challenging issue of bacterial contamination commonly experienced when feeding calves.

Milk acidification against $M$. bovis type strain (ATCC 25523) using Salstop to $\mathrm{pH} 3.5$ and $\mathrm{pH} 4$ led to elimination of viable $M$. bovis after just $1 \mathrm{~h}$ of exposure time. This result may not be surprising given the bacteria's lack of cell wall, as well as its fastidious growth requirements with an ideal $\mathrm{pH}$ for the growth of $M$. bovis in broth being 7.6 (Nicholas et al., 2008). The sensitivity of Mycoplasma spp. to changes in $\mathrm{pH}$ was highlighted in an earlier study looking at porcine Mycoplasma hyorhinis, with significantly less growth found when the broth pH was reduced to just 6.5 (Dinter and TaylorRobinson, 1969). For Salmonella Dublin strain 380, elimination of the organisms at $\mathrm{pH} 3.5$ and $\mathrm{pH} 4$ was slower and was not observed until 2 and 6 h of exposure, respectively. This outcome is similar to a previous trial that evaluated total aerobic colony counts of bacteria following acidification of BTM with formic acid, with no bacterial growth observed after 3 to $21 \mathrm{~h}$ of contact at a $\mathrm{pH}$ of 4.2 (Anderson, 2005b). Our results indicate that $M$. bovis is more sensitive to changes in $\mathrm{pH}$ than other bacterial species commonly found in milk.

For milk treated to $\mathrm{pH} 5$, slight differences were observed in results between replicate trials 1 and 2 for M. bovis type strain (ATCC 25523). In trial 1, growth decreased at $6 \mathrm{~h}$, with no growth from $8 \mathrm{~h}$ onwards. However in trial 2, growth decreased earlier, at $2 \mathrm{~h}$, with no growth after $4 \mathrm{~h}$. This pattern may have been due to the slight difference in the actual mean $\mathrm{pH}$ for each trial. Trial 1 had a slightly higher mean $\mathrm{pH}$ of 5.29 , while trial 2 had a mean $\mathrm{pH}$ of 5.07. Although this difference in $\mathrm{pH}$ is only minor, it suggests that $\mathrm{pH}$ 5 may be the critical level at which only slight variances can cause changes in the necessary exposure time required to affect $M$. bovis growth and viability. From our data looking at $M$. bovis type strain (ATCC 25523) and Salmonella Dublin strain 380, acidification of milk to $\mathrm{pH} 4$ would be necessary to ensure elimination of viable $M$. bovis organisms after $1 \mathrm{~h}$ of exposure. Dropping milk to $\mathrm{pH} 4$ has the added benefit of eliminating viable Salmonella Dublin organisms after $6 \mathrm{~h}$ of exposure. However, because these trials were only performed on 1 strain of each pathogen, it is possible that not all strains would behave the same and, as such, some variation in responses may be seen. While beyond the scope of this paper, future studies could be directed at investigating strain variation.

During the milk acidification process, slight milk separation was observed for treatments $\mathrm{pH} 5$ and lower. However, gentle mixing returned the milk to a homogenous solution with some fat remaining fixed to the 
inside of the glassware. Separation occurs as the $\mathrm{pH}$ of milk is reduced because of the coagulation of casein into a solid mass (Kruif, 1996). Casein is a protein that makes up $82 \%$ of total milk proteins, with $18 \%$ of total proteins remaining in the whey (Fox et al., 2015). Total separation to the point of a "cottage cheese-like" consistency that cannot be resuspended into solution has been reported in acidification of warm or hot milk (Anderson, 2008) and in preliminary trials conducted as part of this study in which constant agitation of the acidified milk occurred (results not shown). This modification to the milk components may affect calf nutrition because of the possibility of calves only consuming the milk whey. Therefore, if milk acidification is being considered as a treatment option for calf milk, managing its preparation and delivery to calves to avoid complete milk separation to the point that it cannot be returned to a homogenous solution is very important. For example, piping acidified milk over long distances may cause excessive agitation and milk separation, with the milk solids coating the inside of the pipes and only the whey being received and consumed by the calves. A much simpler system involving preparation of milk in buckets that are directly transported to calf feeders may therefore be necessary. As such, from a practical viewpoint, milk acidification may be more suitable for smaller dairy systems. Apart from physical separation, little information is available on the direct effect of acidification on the nutritional value of milk as a whole. However, studies assessing its impact on calf performance attributes including weight gain, feed intake, and feed efficiency have found no significant difference between calves fed acidified and normal milk (Jaster et al., 1990; Guler et al., 2006; Metin et al., 2006). These studies did provide positive outcomes including the reporting of significantly lower fecal consistency scores and a significantly lower incidence of diarrhea for calves receiving acidified milk.

Throughout the 24-h sampling period for milk acidification trials against $M$. bovis type strain (ATCC 25523) and Salmonella Dublin strain 380 in heat-treated milk, the $\mathrm{pH}$ remained stable for each treatment group once the desired $\mathrm{pH}$ was achieved, with the exception of the Salmonella Dublin positive control, which showed a slight decline at $24 \mathrm{~h}$. This outcome is an important aspect for 2 reasons. First, it has been suggested that with a $\mathrm{pH}$ below 4, calves find acidified milk less appealing (Anderson, 2005a). It is therefore important that the $\mathrm{pH}$ does not continue to decrease once the milk has been adjusted to the desired $\mathrm{pH}$. Second, if the $\mathrm{pH}$ increases over time, this will affect the ability to eliminate viable $M$. bovis and Salmonella Dublin should the milk become contaminated following treatment. The stability of $\mathrm{pH}$ at $3.5,4$, and 5 was confirmed in acidified hospital herd milk containing a mixed bacterial load. However, the control hospital herd waste milk and that acidified to a $\mathrm{pH}$ of 6 experienced a sharp decline in $\mathrm{pH}$ at $24 \mathrm{~h}$, consistent with microbial fermentation and production of lactate. Therefore, if it is necessary to feed acidified waste milk with an initial high mixed bacterial load, ensuring an adequately low starting $\mathrm{pH}$ is essential for $\mathrm{pH}$ stability.

\section{CONCLUSIONS}

This study is the first of its kind to evaluate the use of milk acidification at various $\mathrm{pH}$ values and exposure times to eliminate viable M. bovis and Salmonella Dublin organisms in infected milk for type strains ATCC 25523 and strain 380, respectively. Although $M$. bovis was unable to proliferate in milk, its viability was dependent on the concentration of organisms and storage temperature conditions. Conversely, Salmonella Dublin was able to exponentially proliferate in milk at 23 and $37^{\circ} \mathrm{C}$. Therefore, treating milk infected with $M$. bovis and Salmonella Dublin is necessary before calf consumption to eliminate viable organisms and to assist in preventing possible disease transmission via this route. Although the safest and recommended option is to not feed waste milk to calves, on farms where it may be necessary, acidification of milk using the acidifying agent Salstop is effective at eliminating viable $M$. bovis and Salmonella Dublin organisms in milk if the appropriate $\mathrm{pH}$ and exposure times are maintained. This trial provides evidence to support that the ideal $\mathrm{pH}$ to achieve these results is $\mathrm{pH} 4$ with an exposure time of 1 $\mathrm{h}$ for $M$. bovis and $6 \mathrm{~h}$ for Salmonella Dublin, with the $\mathrm{pH}$ remaining stable over a period of $24 \mathrm{~h}$.

\section{ACKNOWLEDGMENTS}

The authors acknowledge Dairy Australia (Southbank, VIC, Australia) for their financial support. The technical assistance provided by Anne-Marie House and Karen Mathews from the Faculty of Veterinary Science, The University of Sydney, is greatly appreciated. Statistical advice provided by Evelyn Hall from the University of Sydney has also been invaluable. Salstop SD was provided free of charge by Feedworks Pty Ltd. (Romsey, VIC, Australia). Feedworks Pty Ltd. does not manufacture Salstop; however, it is a commercial outlet for the purchase of Salstop. The authors have no other conflicts of interest to declare.

\section{REFERENCES}

Anderson, N. G. 2005a. Making acidic milk with formic acid for ad libitum feeding to calves. CEPTOR Animal Health News 13:9-11. 
Anderson, N. G. 2005b. Plate loop count of acidified, raw, bulk tank milk. CEPTOR Animal Health News 13:14-15.

Anderson, N. G. 2008. Experiences with free-access acidified-milk feeding in Ontario. Pages 12-24 in Proc. 41st Annual Conf. Am. Assoc. Bovine Pract., Charlotte, NC. Am. Assoc. Bovine Pract., Auburn, AL.

Boonyayatra, S., L. K. Fox, T. E. Besser, A. Sawant, and J. M. Gay 2010. Effects of storage methods on the recovery of Mycoplasma species from milk samples. Vet. Microbiol. 144:210-213.

Butler, J. A., S. A. Sickles, C. J. Johanns, and R. F. Rosenbusch. 2000. Pasteurization of discard mycoplasma mastitic milk used to feed calves: Thermal effects on various mycoplasma. J. Dairy Sci. $83: 2285-2288$

Byrne, W., B. Markey, R. McCormack, J. Egan, H. Ball, and K. Sachse. 2005. Persistence of Mycoplasma bovis infection in the mammary glands of lactating cows inoculated experimentally. Vet. Rec. 156:767-771.

Dinter, Z., and D. Taylor-Robinson. 1969. Susceptibility and resistance of various strains of Mycoplasma hyorhinis to antisera, polymyxins and low pH values. J. Gen. Microbiol. 57:263-272.

Fox, P. F., T. Uniacke-Lowe, P. L. H. McSweeney, and J. A. O'Mahony. 2015. Dairy Chemistry and Biochemistry. 2nd ed. Springer International Publishing, Cham, Switzerland.

Gelsinger, S. L., A. J. Heinrichs, C. M. Jones, R. J. Van Saun, D. R. Wolfgang, C. M. Burns, and H. R. Lysczek. 2014. Efficacy of onfarm use of ultraviolet light for inactivation of bacteria in milk for calves. J. Dairy Sci.9729902997

Godden, S., S. McMartin, J. Feirtag, J. Stabel, R. Bey, S. Goyal, L. Metzger, J. Fetrow, S. Wells, and H. Chester-Jones. 2006. Heattreatment of bovine colostrum. II: Effects of heating duration on pathogen viability and immunoglobulin. J. Dairy Sci. 89:34763483.

Godden, S. M., J. P. Fetrow, J. M. Feirtag, L. R. Green, and S. J. Wells. 2005. Economic analysis of feeding pasteurized nonsaleable milk versus conventional milk replacer to dairy calves. J. Am. Vet. Med. Assoc. 226:1547-1554.

Guler, O., M. Yanar, B. Bayram, and J. Metin. 2006. Performance and health of dairy calves fed limited amounts of acidified milk replacer. S. Afr. J. Anim. Sci. 36:149-154.

House, J. K., B. P. Smith, G. W. Dilling, and L. Daroden. 1993 Enzyme-linked-immunosorbent-assay for serologic detection of Salmonella Dublin carriers on a large dairy. Am. J. Vet. Res. 54:1391-1399.

Izzo, M., V. Mohler, and J. House. 2011. Antimicrobial susceptibility of Salmonella isolates recovered from calves with diarrhoea in Australia. Aust. Vet. J. 89:402-408.

Jamaluddin, A. A., T. E. Carpenter, D. W. Hird, and M. C. Thurmond. 1996. Economics of feeding pasteurized colostrum and pasteurized waste milk to dairy calves. J. Am. Vet. Med. Assoc. 209:751-756.

Jaster, E. H., G. C. McCoy, T. Tomkins, and C. L. Davis. 1990. Feeding acidified or sweet milk replacer to dairy calves. J. Dairy Sci. 73:3563-3566.

Justice-Allen, A., J. Trujillo, R. Corbett, R. Harding, G. Goodell, and D. Wilson. 2010. Survival and replication of Mycoplasma species in recycled bedding sand and association with mastitis on dairy farms in Utah. J. Dairy Sci. 93:192-202.

Kruif, C. G. 1996. Skim milk acidification at low temperatures: A model for the stability of casein micelles. Neth. Milk Dairy J. 50:113-120.
Maunsell, F., M. B. Brown, J. Powe, J. Ivey, M. Woolard, W. Love, and J. W. Simecka. 2012. Oral inoculation of young dairy calves with Mycoplasma bovis results in colonization of tonsils, development of otitis media and local immunity. PLoS ONE 7:e44523.

Maunsell, F. P., and G. A. Donovan. 2009. Mycoplasma bovis infections in young calves. Vet. Clin. North Am. Food Anim. Pract. $25: 139-177$.

Maunsell, F. P., A. R. Woolums, D. Francoz, R. F. Rosenbusch, D. L. Step, D. J. Wilson, and E. D. Janzen. 2011. Mycoplasma bovis infections in cattle. J. Vet. Intern. Med. 25:772-783.

Metin, J., M. Yanar, O. Guler, B. Bayram, and N. Tuzemen. 2006 Growth, health and behavioural traits of dairy calves fed acidified whole milk. Indian Vet. J. 83:976-979.

Mohler, V. L., M. M. Izzo, and J. K. House. 2009. Salmonella in calves. Vet. Clin. North Am. Food Anim. Pract. 25:37-54.

Nicholas, R., R. Ayling, and L. McAuliffe. 2008. Isolation and growth of mycoplasmas from ruminants. Pages 3-14 in Mycoplasma Diseases of Ruminants. CABI, Cambridge, MA; Wallingford, UK.

Pereira, R. V., M. L. Bicalho, V. S. Machado, S. Lima, A. G. Teixeira L. D. Warnick, and R. C. Bicalho. 2014. Evaluation of the effects of ultraviolet light on bacterial contaminants inoculated into whole milk and colostrum, and on colostrum immunoglobulin G. J. Dairy Sci. 97:2866-2875.

Smith, B. P., D. G. Oliver, P. Singh, G. Dilling, P. A. Martin, B. P. Ram, L. S. Jang, N. Sharkov, J. S. Orsborn, and K. Jackett.. 1989. Detection of Salmonella Dublin mammary gland infection in carrier cows, using an enzyme-linked immunosorbent assay for antibody in milk or serum. Am. J. Vet. Res. 50:1352-1360.

Stabel, J. R., S. Hurd, L. Calvente, and R. F. Rosenbusch. 2004. Destruction of Mycobacterium paratuberculosis, Salmonella spp., and Mycoplasma spp. in raw milk by a commercial on-farm high-temperature, short-time pasteurizer. J. Dairy Sci. 87:2177-2183.

Stewart, S., S. Godden, R. Bey, P. Rapnicki, J. Fetrow, R. Farnsworth, M. Scanlon, Y. Arnold, L. Clow, K. Mueller, and C. Ferrouillet. 2005. Preventing bacterial contamination and proliferation during the harvest, storage, and feeding of fresh bovine colostrum. J. Dairy Sci. 88:2571-2578.

Teixeira, A. G., M. L. Bicalho, V. S. Machado, G. Oikonomou, C. Kacar, C. Foditsch, R. Young, W. A. Knauer, D. V. Nydam, and R. C. Bicalho. 2013. Heat and ultraviolet light treatment of colostrum and hospital milk: Effects on colostrum and hospital milk characteristics and calf health and growth parameters. Vet. J. 197:175-181.

Veling, J. 2004. Diagnosis and control of Salmonella Dublin infections on Dutch dairy farms. PhD Thesis. Animal Health Service, Deventer, the Netherlands.

Vyletelova, M. 2010. The survival of Mycoplasma bovis at different temperatures. Czech J. Food Sci. 28:74-78.

Wilson, D. J., R. T. Skirpstunas, J. D. Trujillo, K. B. Cavender, C V. Bagley, and R. L. Harding. 2007. Unusual history and initial clinical signs of Mycoplasma bovis mastitis and arthritis in firstlactation cows in a closed commercial dairy herd. J. Am. Vet. Med. Assoc. 230:1519-1523.

Wray, C., and R. H. Davies. 2000. Salmonella infections in cattle. Pages 169-190 in Salmonella in Domestic Animals. CABI Publishing, Wallingford, UK.

Wray, C., and W. J. Sojka. 1977. Reviews of the progress of dairy science: Bovine salmonellosis. J. Dairy Res. 44:383-425. 